\title{
Vietnam's Underground Economy: Where "Sharks" Were Food
}

\author{
Stratfor
}

Since mid-200os, Vietnamese have paid much more attention to financial investments and transactions. This is not to say that individual investments had not been in place before the time, but the scale of private financial transactions and the degree of attention brought to the public had never been as large and high as since mid-20oos.

The reasons for the general public's hope in financial investments and other speculative assets are quite understandable. Since early 1990s, about 4 waves of price increases were taking place in the domestic real property market. [1] In Hanoi, for instance, land prices in "the old Hanoi" - meaning the first 4 "inner city districts" as Hanoians usually called them, Hoan Kiem, Ba Dinh, Hai Ba Trung, Dong Da - increased like 10-40 times if land price calculation money is gold, and 100-200 times if the money is the local currency, i.e. the Vietnamese Dong, between these two points in time.

Also, people wished to have more money for spending. Unlike the centrally planned economy, when everything was planned and every price was pre-determined - also in plans, markets brought flexibility, diversity and uncertainty of goods and money to the public. In late 1990s, Vietnamese even in major cosmopolitan centers for the first time heard of "happy shopping." Today, after only 10 years, "shopaholic" could hardly be anything strange, no matter we talk about junior high girls or mid-career state employees (who may still need family financial supports at times, especially at inflation times). The more they are willing to spend, the more they want to have quick money, no matter if the money is dirty or too hot.

Today, if you sit down in the corner of a cafe in downtown Hanoi, and you could understand Vietnamese 95 percent of the time, people talk about money around the coffee tables. It sounds strange to foreigners, but this is true, Vietnamese today could repeat the word "money" 1,000 times in less than an hour as if every time they uttered the word, their accounts elsewhere would be credited.

Last but not least, "life is so short" syndrome has been common. When people have more money and assets, they enjoy life. Of course, this is not anything new, but when there are more people living like that around, everyone is adversely affected. The trend is: everyone tries to work less and earn more. Why? Because "life is so short" and rich people could not bring money with them to the other world!

That's why a poor country with $\$ 1,000$ per capita annual GDP and substantial external debts could spend money at the staggering speed 
that could stun foreign businesspeople coming to Vietnam the first time. Vietnam imported over $\$ 1$ billion worth luxury auto brands each recent year, bringing Porsche, Ferrari, Mercedes Benz, Cadillac... to Vietnamese cramped urban streets. Simple: Life is so short, and we could not "delay our happiness," the Vietnamese saying excerpted from a famous local film touching the Vietnamese transition in rural areas.

There are more things we can talk about, since such a vibrant transition of a 90 million nation has definitely carried with it tons of stories worth telling (since you could hardly learn those from anywhere else). But why all these are relevant to the title of some sharks being eaten?

The logic is becoming crystal clear, right here. Almost everyone dreams of some kind of "money machine" which produces money constantly and quickly. So go get it! They try everything, stock market, real estate speculation, gold hoarding, online forex trade accounts, and so on and so forth...

Perhaps the easiest one and also considered "very conventional" form of money machine is usury. It is very understandable, easy to learn and ready to spread around. Normal people also like lending to some "trustworthy people" at a "reasonably high" rate, such as 5, 6, 7 percent per month!? (or 60-80 percent per annum.)[2] Now we all call this an American term: Ponzi scheme.

In Vietnam, as in other places in the world, somewhere in the past, history repeats itself so many times. Past extremely painful collapses of this huge money machine did not scare people away. Why? Because the wish for quick, hot and perhaps dirty money is too grandiose. Second, most believe that problems would tend to happen to "someone else, not me or us." And third, there is a kind of perceived safety when acting in a herd. To many, there is nothing to worry about when you act the way the large crowd follows.

Now the world economy history offered so many lessons telling us that herd mentality has been at the heart of market panic, boom-burst cycles, depression, large-scaled creditcrunch, bank runs...

"Usurers" are evil in Vietnam history and usury is taboo. But normal people love living like usurers, love having a Bentley car or Porsche SUV, shopping in a 6-star highrise downtown and eating in an Accor Sofitel restaurant where Belgian Duvel beer is served... The tale of Cinderella is appealing, of course. Here Cinderella looks - to them - like a loan shark, which enjoys huge monthly interest and lives a happy life without working too much, perhaps 1-2 hours per day in air-conditioned environment.

And the dream goes on for ever, even when harsh realities prove that normal people could not attain extreme positive returns from assets without facing some kind of black-swan risk of failure. It happened repeatedly in the past and greed continues to manifest itself through a wide variety of Ponzi games. The following fresh story in Vietnam is a new evidence. 
The Lao Dong Newspaper reported on Jul 4, 2011 that many "loan sharks" in Phu Cat Dist. of Binh Dinh Province became empty-handed after realizing that their debtor - a "very large and trustworthy local business operation" went belly up. The lost amount of money could reach millions of US dollars.

A pair in Phu Cat offered 6 percent monthly interest rate to their "loan sharks." These "sharks" collateralized their lands, houses for most expensive bank loans and also borrowed from other underground lenders, i.e. first-order sharks, at prohibitively high rate (remember all their loans were also unsecured).

In fact, these gullible "sharks" borrowed funds at 4.5 to 5.0 percent per month (50-60 pct p.a.) and then loaned them out to the husband-wife business operation as said above at 6 pct p.a. Of course, they paid well over the first few months when the reputation of on-time payment drew more rural private lenders. When the money owed by the pair reached millions of dollars, it turned out so tough for them to pay even part of the interest expense since the flows diminished over time.

The scheme then collapsed, hence the newspaper story. Typical Ponzi scheme. Nothing new.

When encountering this kind of loss, optimistic Vietnamese usually say: "Oh, it is my destiny that I lost this money." "Destiny" and "fate" are major workhorses in Vietnam's transition financial system since problems with sour investments and losses from stock market betting being so familiar. For these normal people, who wished to enjoy extremely high monthly interest payment, in fact they had other option than the "destiny" frequently referred to: Not to become a voluntary, naive and unskilled loan shark.

Follow the news line in Vietnam, you could see more of this happen.

* Notes:

[1] Vương Quân Hoàng và Phạm Minh Chính, Kinh tế Việt Nam: Thăng trầm và Đột phá, tr. 299-302, NXB Chính trị Quốc gia, 2009

[2] During Tet Holiday (Jan-Feb 2011) a Hanoi-based eco-resort developer tried to borrow money at monthly interest rate of 15 percent. While for a consumption loan which is less than VND 50 million, HSBC currently offers an interest rate of 25 pct per year. 


\section{References}

Phạm Minh Chính, Vương Quân Hoàng. (2009). Kinh tế Việt Nam: Thăng trầm và đột phá. Nxb Chính trị quốc gia, Hà Nội.

Lao Động. (2011). Vỡ nợ hàng chục tỉ đồng, nhiều chủ nợ trắng tay.

http://laodong.com.vn/Tin-Tuc/Vo-no-hang-chuc-ti-dong-nhieu-chu-notrang-tay/48746 